\title{
Ciência, publicação e redação científica
}

\author{
Gilson Luiz Volpato
}

Espera-se que cada achado divulgado por uma publicação científica traga a uma área de estudo novas soluções e insights. Nessa tarefa, o papel do cientista é de extrema importância, uma vez que a ciência é um veículo por meio do qual interpretamos o mundo e o conhecimento científico é um constructo baseado em evidência empírica convincente.

Os cientistas focam as observações em dados empíricos (acessíveis às nossas modalidades sensoriais) e constroem explicações de modo a melhor compreendermos aspectos do mundo natural. Tais explicações, ainda que baseadas em achados empíricos, são apenas proposições teóricas que, em última análise, necessitam aceitação por uma porcentagem significativa de especialistas na respectiva área. Sem esse reconhecimento, a explicação proposta permanece escondida. Essa realidade significa que a ciência apenas nos fornece discursos abstratos (interpretações), mesmo que baseadas em evidências empíricas.

Nesse contexto, os cientistas devem comunicar suas conclusões (suas explicações baseadas em achados empíricos) aos seus pares acadêmicos, uma tarefa que é atingida pela publicação em uma revista científica. O texto submetido para publicação, no entanto, deve passar por uma revisão editorial feita por membros anônimos da academia. Se o texto é finalmente aceito para publicação, o desafio para construir conhecimento científico apenas começou.

$\mathrm{Na}$ academia científica, o objetivo principal de um cientista é convencer seus pares sobre a validade de suas conclusões. A utilização de evidências empíricas fortes e a autoridade acadêmica estimada da revista na qual o estudo é publicado facilitam esse discurso. Uma vez atingido esses requisitos, o artigo ainda precisa ser baixado e lido e sua conclusão deve ser aceita pelos especialistas na respectiva área. Tal aceitação pelos especialistas é a tarefa mais desafiante para um cientista. Se os achados empíricos apresentados em um artigo não são convincentes para seus leitores, o artigo pode ser rapidamente descartado. O status acadêmico da revista, o título do artigo, seu resumo, suas figuras e tabelas e sua qualidade da redação também podem fazer com que os leitores rejeitem as conclusões publicadas pelo autor. Esses são os mais importantes desafios que um cientista deve ultrapassar.

A redação científica é uma forma de comunicação que habilita os cientistas a apresentarem conclusões efetivamente. No entanto, este assunto tem sido tratado apenas por meio de técnicas linguísticas em todo o mundo. Regras práticas têm sido impostas para assegurar que os cientistas escrevam de forma concisa e com clareza, objetividade e lógica. O entendimento dessas regras, no entanto, é o aspecto menos importante do problema.

O discurso científico é direto e simples: estabelece-se o raciocínio subjacente a um objetivo, do qual se derivam passos metodológicos para finalmente construir resultados para descrever variáveis ou testar hipóteses; esses resultados e conclusões são sustentados por conhecimento publicado e espera-se que se construam novas conclusões gerais. Embora aparentemente simples, esse processo é complexo e sustentado por bases filosóficas.

Erros na redação são erros no raciocínio. No contexto específico do Brasil, muitas atitudes culturais e tendências linguísticas nos impedem de atingir a simplicidade requerida para uma redação científica eficiente. Os brasileiros apreciam textos longos, comunicação complexa, resultados excessivos, expressões prolixas e ideias que confirmam conhecimento já adquirido, entre outras tendências de comunicação.

Os cientistas brasileiros necessitam urgentemente de uma revolução no pensamento. Nossos cursos de pósgraduação não têm sido bem sucedidos na superação dessas barreiras de pensamento. Devemos ser empreendedores ao visualizarmos a evolução do conhecimento e devemos nos aventurar sem medo em pensamentos inovadores. Com uma mudança de mentalidade, o desenvolvimento científico se tornará uma realidade em nosso país e nosso progresso poderá vir a ser reconhecido com um prêmio Nobel. Com essas mudanças, teremos os meios necessários para nos mover em direção a uma sociedade melhor.

${ }^{\mathrm{I}}$ Departamento. de Fisiologia, Instituto de Biociências, Botucatu, SP, Unesp. 